Man and Nature

MAN AND NATURE

L'homme et la nature

\title{
The Individual and the Collective in Eighteenth-Century Language Theory
}

\section{Nicholas Hudson}

Volume 10, 1991

URI : https://id.erudit.org/iderudit/1012623ar

DOI : https://doi.org/10.7202/1012623ar

Aller au sommaire du numéro

Éditeur(s)

Canadian Society for Eighteenth-Century Studies / Société canadienne d'étude du dix-huitième siècle

ISSN

0824-3298 (imprimé)

1927-8810 (numérique)

Découvrir la revue

Citer cet article

Hudson, N. (1991). The Individual and the Collective in Eighteenth-Century Language Theory. Man and Nature / L'homme et la nature, 10, 57-66.

https://doi.org/10.7202/1012623ar

Copyright (c) Canadian Society for Eighteenth-Century Studies / Sociéte canadienne d'étude du dix-huitième siècle, 1991
Ce document est protégé par la loi sur le droit d'auteur. L'utilisation des services d'Érudit (y compris la reproduction) est assujettie à sa politique d'utilisation que vous pouvez consulter en ligne.

https://apropos.erudit.org/fr/usagers/politique-dutilisation/ 


\section{The Individual and the Collective in Eighteenth-Century Language Theory}

In 1836, Wilhelm von Humboldt described the creation and evolution of any language as the collective effort of an entire nation. This thesis reflected an important change in the understanding of language that occurred during the previous century. Philosophers in the seventeenth century had argued that words referred exclusively to the private thoughts of the individual. Thomas Hobbes theorized on the creation of language by a solitary reasoner; John Locke argued that 'Words in their primary and immediate signification, stand for nothing, but the Ideas in the Mind of him that uses them' (405). ${ }^{1}$ But for Humboldt, language 'could only proceed from everybody at once; each individual would have had to be carried therein by the others, for inspiration gains new uplift only through the assurance of being felt and understood' (24). Because every person achieved articulation and reason only through 'communal thinking with others' (27), the individual was of minor importance in linguistic research. Humboldt's interest was almost solely in the language of the nation or 'race.'

In this essay, I will trace the gradual shift towards doctrines such as Humboldt's that stressed collective tongues and 'communal thinking.' As we shall see, the views of linguistic philosophers of the eighteenth century tended to fall between the poles represented by Locke and Humboldt: Condillac and Herder both described a dynamic and mutually productive interaction between national speech and personal dialect. Theories affirming the social origin of speech emerged as part of the effort by these authors to construct a coherent philosophy of language: the theory that language refers solely to the thoughts of the individual raised logical difficulties that were solved by locating the origin of language in dialogue and social interaction.

It is important to remark, first, that discussions of the individual and collective can have no place in theories that assume the divine origin of language. Such discussions became relevant only when philosophers and theologians of the seventeenth century began to challenge the belief that God miraculously bestowed language on Adam in paradise. These attacks on belief in the divine origin of language did not necessarily come 
from free-thinkers and heretics: in Histoire critique du Vieux Testament (1678), the French priest Richard Simon undertook a prolonged attack against Adamic language theory in the service of the counter-reformation. Aiming to destroy Protestant confidence in the words of Scripture, unsupported by the traditions of the Catholic Church, he argued that language is the imperfect creation of human beings. In a 1685 rebuttal to Simon, the Protestant author Jean le Clerc remarked angrily that Simon sounded more like a pagan than a member of the Christian Church. Simon's ideas, argued leClerc, implied the degrading image of Adam and Eve babbling and gesturing helplessly in the Garden of Eden: ' $c$ 'est en verité se former une belle idée de nos premiers parens, que de se les représenter comme deux muets, qui ne peuvent d'abord que former des sons inarticulez, \& se faire quelques signes l'un à l'autre' (424). Despite le Clerc's pious intentions, it was this image of Adam and Eve trying to communicate in the Garden of Eden which, during the next century, inspired some of the major theories on the human origin of language. Bernard Mandeville, for example, scented the opportunity for a shocking heterodoxy. In the second part of The Fable of the Bees (1729), Mandeville transformed Adam and Eve into a 'wild couple,' totally abandoned to their appetites, and lacking any language except lewd gestures and lustful grunts (cf. 2:286-89). ${ }^{3}$ In Essaie sur l'origine des connaissances humaines (1746), the Abbé Condillac used the model of 'deux enfants' in a desert who gradually recognized the usefulness of articulate sounds to express their needs and wants. Condillac is of special interest here because it is this philosopher, so influential on writers of later decades, who developed the thesis that language must be the product of social interaction. Condillac's version of Adam and Eve exemplifies an original linguistic community, for, as he argues, 'les hommes ne peuvent se faire des signes, qu'autant qu'ils vivent ensemble' (1:47). The two children represent the first stage in the evolution of a language which moulds and gives expression to a collective identity and social habits of mind.

According to Condillac, the articulate word is essential to our ability to reason coherently about the world and ourselves. By means of the word, we can recall objects that we have perceived in the past; we can draw various ideas together in our minds and examine their connections. A word also bestows 'le pouvoir... de disposer de notre attention' (1:22), for we gain the ability to move our thoughts at will from one sensation to another. Thus, the word is the primary basis of volition, for it makes us 'maîtres de l'exercice de notre imagination' (1:22). Before the word, we were directed only by the spontaneous impulse of our instincts and appetites; with the discovery of the word, we became conscious of these appetites, and were able to direct our actions with freedom and efficiency towards the satisfaction of our wants. 
This theory on the close inter-connection between language and reason raises certain problems. Condillac assumed that language was discovered by humans, not bestowed by God, yet the recognition of how the word might be useful to organize and direct our thoughts seems beyond the comprehension of primitive people who lacked reason and volition. As Condillac remarked, 'Il semble qu' on ne sauroit se servir des signes $\mathrm{d}$ 'institution, si l'on n'étoit pas déjà capable d'assez de réflexion pour les choisir et pour y attacher des idées' (1:22). It was, in part, this problem that led Condillac to adopt the model of the two children in a desert. Language must have been, from the very first, the joint discovery of individuals who together developed not only a method of speaking, but, more profoundly, a whole way of understanding themselves and the world. One child would recognize through long habit that the cries and gestures of the other indicated certain desires and needs. At this point the child would also discern that his own cries and gestures indicated the same passions. In this way, the individual would begin to understand himself through the signs of his partner; dialogue would stir the first efforts of conscious reflection. As Condillacasserted, 'Puisqueles hommes ne peuventse faire des signes, qu'autant qu'ils vivent ensemble, $c^{\prime}$ est une conséquence que le fonds de leurs idées, quand leur esprit commence à se former, est uniquement dans leur commerce réciproque' (1:47).

The creation of ideas and reason is therefore inextricably bound up with the social exchange of language. At a fundamental level, the individual is shaped by society, and as the two children went on to develop more sophisticated forms of expression, they also formed ways of thinking that corresponded with their shared concerns and aspirations. The social origin of the individual consciousness is still evident in modern languages. The language of every nation reflects the natural environment and habits of mind that have induced a characteristic way of connecting ideas and understanding the world. 'Je demande,' wrote Condillac, 's'il n'est pas naturel à chaque nation de combiner ses idées selon le génie qui lui est propre, et de joindre à un certain fonds d'idées principales différentes idées accessoires, selon qu'elle est différemment affectée' (1:103).

But Condillac does allow for important differences in the language of individual speakers in the same culture. And this belief, as we shall see, is important to his thesis on how languages progress towards ever greater perfection. 'Il ne faut qu'étudier un homme quelque temps,' affirmed Condillac, 'pour apprendre son langage: je dis, son langage, car chacun a le sien, selon ses passions' (1:98). Because we all have different psychological make-ups, and we all experience different facets of the world in varying ways, we also have personal dialects. This dialect embodies and 
mediates between our social and private existence. It also offers a possible solution to a difficulty with Condillac's vision of linguistic evolution.

According to Condillac's thesis, we are able to conceive of ourselves and of the world only to the extent that we possess a nomenclature that fixes and organizes our ideas. While language bestows volition over our ideas, it is therefore also confining, for we seem powerless to understand the world in ways that vary from the linguistic system of our culture: 'accoutumés à concevoir les choses de la même manière qu'elles étoient exprimées dans la langue que [les hommes] avoient apprise en naissant, leur esprit étoit naturellement rétréci' (1:100). In order for language to increase and progress, the variations in the individual dialect must exert their influence on the collective tongue. And while the ordinary individual may depart in only minor ways from the conventions, the scientific or literary genius is able to conceive forms of expression that add in important ways to the collective vocabulary and phraseology. In order to be understood and exert his influence, the genius must roughly follow what Condillac calls 'les règles de l'analogie' established in a language - that is, the general ways of connecting and expressing ideas that have governed the historical formation of the national idiom. But his improvisation of new connections or analogies within these rules enriches the whole system, and opens new possibilities for linguistic and, hence, intellectual progress: 'les grands hommes... se conforment au génie de leur langue, et lui prêtent en même-temps le leur' (1:101).

Condillac may almost be regarded as an illustration of his own doctrine. His ideas on the linguistic bases of cognition, on the analogies that embrace the entire language of a culture, and on the role of the individual genius, inaugurated a route of investigation and a flexible terminology widely adopted by later theorists. ${ }^{4}$ For instance, it became conventional for grammarians and lexicographers like Samuel Johnson to complain that the influx of foreign terms into a language corrupted its 'settled analogy' or 'general fabric' (Johnson, 311-13). And even the humblest grammarians praised the general 'spirit' and 'genius' of their mother-tongue, and attempted to elucidate those features of the national character reflected in the language.

Yet intellectual history moves forward as often by means of negation and contradiction as by an incremental process of 'influence,' strictly defined. Perhaps nowhere was Condillac's impact greater than when innovative minds tried to show that he was wrong. Jean-Jacques Rousseau, for example, denied the possibility and relevance of Condillac's 'deux enfants.' As Rousseau remarked of Condillac in Discours sur l'origine de l'inégalité (1754), 'il a supposé ce que je mets en question, savoir une sorte de société déjà établie entre les inventeurs du langage' (3:146). In the state of nature before language, individuals would be 
scattered across the globe. They would have no need for dialogue, for they would be entirely independent and self-sufficient, impelled with sureness by the spontaneous promptings of instinct. The appearance of language was, for Rousseau, a great mystery, partly because human beings were happier without it, and partly because he insisted that its invention exceeded the intellectual capacities of savages. Rousseau agreed with Condillac that language created new bonds between people, integrating the individual into the collective values and aspirations of a culture. But this collectivization has made people not happier, but more miserable, not better, but more corrupt. By facilitating the introduction of collective activities such as agriculture, and by instituting general laws of morality, property and so forth, language alerted people to their physical and intellectual inequalities, suppressed pity under the utilitarian value of the 'common good,' and made possible the pursuit of personal interests by means of slavery and mutual exploitation. ${ }^{5}$

Less well-known to scholars outside the area of linguistic theory is the work of James Burnett, Lord Monboddo, whose six volumes on The Origin and Progress of Language (1773-92) refuted both Condillac and Rousseau. ${ }^{6}$ Against these writers, Monboddo denied that the invention of language was necessary to the foundation of society. Indeed, society must have reached an advanced level of organization before people could have set themselves the task of developing a language more sophisticated than gestures and inarticulate cries. The logic of Monboddo's argument owed something to Rousseau: the inspiration to use articulate sounds to express our thoughts was far beyond the meagre capacities of two children in a desert. In fact, the development of language would require such feats of metaphysical reasoning, its grammatical structures reveal such a profound understanding of nature, that it could not possibly have been the product of popular effort over a long period of time: 'the art of language... could not have been produced by mere people, but must have been the work of artists, and men of superior abilities' (2:6). Society must have reached a level of political stability and economic prosperity sufficient to support a class of philosophers who were at leisure to devote all their time and effort to the study of articulation. Moreover, language was fashioned in accordance with the lofty principles of art and reason, and not in response to national values and aspirations. Monboddo's deeply conservative understanding of society envisions a privileged class of artificers bestowing their discoveries on a passive and obedient people: 'man being naturally a docile and imitative animal, would be disposed to copy whatever he saw was better of the kind than what he had been use to practise. And this would hold especially, if the new method was recommended by men of authority' (2:497). Language was thus the product of a select class of scholars, not 
the collective genius of a nation, a thesis which Monboddo proudly compared with Plato's ideal of the philosophical republic (cf. 2:483).

Monboddo's political vision was neither appealing nor convincing to later writers, but he exemplified an important characteristic of language theory in his time. If seventeenth-century authors likeBacon, Hobbes, and Locke had regarded language as a highly imperfect system, authors of the mid eighteenth century dwelled enthusiastically on the great genius required to make even the first steps toward articulation. The challenge for theorists like Johann Gottfried Herder was to show how this act of genius could have been performed by individuals who lacked not only articulate speech, but even the most basic operations of rational thought. Although Herder's argument in his prize-winning Essay on the Origin of Language (1772) would re-affirm Condillac's vision of a national language, infused with the genius of the people, he insisted that the initial step towards the vocal sign must have occurred in the deepest recesses of the individual mind. Because he finds the origin of language in individual reason, not in dialogue, he is dismissive of that beleaguered couple in this story, Condillac's two children. Nonetheless, Herder develops some of Condillac's major insights into the psychology of language: faced with what Herder calls 'a vast ocean of sensations,' the individual would need to fasten on some sign, 'a distinguishing mark,' to separate one impression from the others and begin the work of reducing this confused mass to an organized system (1966: 115-16). ${ }^{7}$ A lamb, to use Herder's example, would appear as a distorted bundle of sensations - white, soft, and woolly. But when the lamb bleated, it would be distinguished from all other objects in nature. The bleat would give the lamb identity, and, held in the memory like a name, would allow the individual to isolate and examine those sensations that together characterize this species. 'Let us acclaim him with shouts of eureka!' Herder exclaims, 'The first distinguishing mark, as it appeared in his reflection, was a work of the soul! With it human language is invented' (1966: 116).

But Herder's work was not quite finished. He had to explain a crucial assumption of his theory - why this primitive human would fasten on a sound, rather than some mark of sight or touch, in order to identify an object. This is important because the vocal mark, like a bleat, could easily be transformed into an onomatopoeic word. The first word for lamb was, presumably, something like 'ba-a-a.' But it is less easy to imagine how this individual could have named what Herder calls 'unsounding' objects like a stone or a plant. Herder's solution to this problem lies in his conception of the mind as a 'tissue' of feelings where each sensation is densely interwoven with the rest. Within this tissue of sensations, sight and feeling and sound bear analogies to each other which reason - which unravels the fabric into its distinct 'filaments' - can hardly 
detect, but which the primitive imagination follows 'by a direct and rapid impulse' (1966: 139). For example, 'The sense of feeling is close to that of hearing. Its epithets - such as hard, rough, soft, woolly, velvety, hairy, rigid, smooth, prickly, etc.... all sound as though one could feel them' (1966: 141). John Locke's blind man was not, in short, so far wrong when he compared the colour red to the sound of a trumpet: the mind is 'a single thinking sensorium commune' (1966: 139) where sensations of sight and feeling naturally inspire an analogous sound, a process which opens the possibility of a comprehensive, oral language. ${ }^{8}$

As we have seen, Herder placed the origin of speech in the mind of the individual. But the capacity to leap from one sensation to another, and hence to create the analogies characteristic of a particular language, was ascribed by Herder to the common 'genius' of a whole people. Like many of his predecessors, especially on the continent, Herder was particularly eloquent on the genius of 'Oriental languages,' such as Hebrew and Arabic: 'Open at random an Oriental dictionary, and you will see the urge to express! How these inventors tore ideas away from one feeling to use then in the expression of another!' (1966: 149). Within the historical process that gives form to a language, the individual inherits the ways of expression characteristic of his culture, and contributes his own inspirations. The individual is a link in an unbroken historical process. His ways not only of speaking, but also of thinking, are connected with the first thought of the first founder of his nation: 'no man lives for himself alone; he is knit into the texture of the whole: he is only one link in the chain of generations, one cipher in the cumulative progression of the species' (1969: 163).

Thus, Herder's Essay increasingly subordinates the role of the individual, so prominent in the early pages, to the shared inspirations and values of the nation. His theory of a national language is comparable with Condillac's, but he differed from the French philosopher in crucial ways. What was most important for Herder was not the role of the individual genius within a linguistic culture but the genius of the entire culture, the capacity of a whole people to fashion a language of richness and feeling. Like Rousseau and Monboddo, he stressed the great difficulty of making a language. The child inherits not only the values and aspirations of his ancestors, but their often arduous struggle to conceive the world and then give their thoughts expression. It is this struggle that gives a culture dignity, and the right of possessing the land it has not only tilled, but has also laboured to name and understand. When a man is asked, 'Who gave you a right to these herbs?' he may justly answer, 'Nature, because she gave me conscious awareness. I have laboured to recognize these herbs, laboured also to teach their characteristics to my wife and son' (1969: 164). 
By stressing the importance of the national as opposed to the individual genius, and by elaborating on the ways in which a language embodies and perpetuates the entire intellectual, artistic and economic history of a people, Herder laid the groundwork for some of the most important trends in linguistic philosophy in the nineteenth century. At this point we should return briefly to where we began in the work of Wilhelm von Humboldt. While Humboldt's theory did allow some latitude for individual dialects, he insisted above all that 'the individualities to be found in the same nation fall within the national uniformity' (152). The character of the single speaker is of minor importance compared to the individuality' of the whole people, for 'every nation... can and must be regarded as a human individuality, which pursues an inner spiritual path of its own' (41). Humboldt's meaning of 'national character' was thus much stronger and deeper than the analogous concept in Condillac or even Herder: a people share a common idiom not only because they have lived and spoken together for many centuries, but because they have a common 'soul' or 'natural disposition' that can be explained only by 'community of descent' (152). Whereas his predecessors showed how language shapes the soul, Humboldt focused in particular on how the national soul shapes the language. Nor are all languages equally valuable or 'successful.' Comparing one language with another, we find evidence not only of differing temperaments and habitats, but moreover of crucial inequalities in 'the mental capacity of nations' (217).

In an important respect, Humboldt represents the culmination of the debate in the eighteenth century: ${ }^{9}$ the debate can go no further because here the collective is the 'individual.' The shift exemplified by Humboldt - from the 'individualist' theories of the late seventeenth century to the 'collectivist' theories that developed during the eighteenth century may seem inconsistent with the popular view that Romantic 'individualism' prevailed over the ideal of social conformity dominant in the eighteenth century. As Hans Aarsleff has argued, however, the long neglected field of thehistory of linguistics may well force us to re-consider ourassumptions about historical periods. ${ }^{10}$ The issues raised by linguistic philosophy during this period went far beyond the narrow limits of grammar or philology. And here perhaps is a reason for recently renewed interest in the linguistic thought of Condillac, Rousseau, Herder, and Humboldt: they shared with us a profound sense of the psychological and the social importance of language. Language was for them not just a passive medium for communication; it was the active and richly productive source of both individual and collective consciousness.

NICHOLAS HUDSON

University of British Columbia 
Notes

1 Cf. Hobbes, ch. 2, 14-16. Locke's insistence in bk. 3, ch. 2 of the Essay on the entirely individual and private basis of language has been a topic of considerable discussion among recent critics. Cf. Kretzmann, 331-47; Land, 31-77; Harris, 108-19.

2 On Humboldt's doctrine of 'national character' and 'race,' cf. especially Manchester, 103-22. Modern historians have often commented on the 'incipient racism' of this doctrine. Cf. Leroy, 29ff; Aarsleff, 'Introduction' to Humboldt, x.

3 Until recently, the importance of Mandeville's contribution to the linguistic debate of the eighteenth century was generally ignored. For work that re-establishes Mandeville's importance, cf. Schreyer, 13-43; Hundert, 169-91.

4 Due largely to the work of Hans Aarsleff, Condillac's enormous influence on later philosophers of language is now widely recognized. Cf. especially 'Tradition of Condillac: The Problem of the Origin of Language in the Eighteenth Century,' in Aarsleff, 1982: 146-209. Cf. also Harris, 120-35.

5 Scholars have traditionally assumed that Rousseau's comments on language are a mere digression from the main issues of the second Discours. In opposition to this view, the centrality of language to Rousseau's thesis is argued by de Man, 135-59.

6 For detailed discussion of Monboddo's language theory, cf. Aarsleff, 1983: 36-41; Land, 159-92.

7 The lack of a full English translation of Herder's two part Essay has forced me to use two separate editions. Herder, 1966, contains all of Part I; Herder, 1969, which I use when citing Part II, contains portions from both parts.

8 Locke's famous discussion of the blind man is in bk. 3, ch. 4 of the Essay, 425. A marked development in the empiricist tradition was an increasing willingness to consider an interrelation between the senses, and even the sensorium commune described by Herder. Cf. also Diderot, 158-59.

9 There has been considerable debate concerning the extent of Humboldt's debt to Condillac rather than Herder, or to the French idéologues as opposed to Kant and Fichte. Nevertheless, most historians would agree that he was 'in a general way within the Herder tradition, carrying forward in many respects Herder's intellectual and cultural legacy' (Sweet, 359).

10 Cf. 'Wordsworth, Language and Romanticism,' in Aarsleff, 1982: 372-81.

\section{Works Cited}

Aarsleff, Hans. 1982. From Locke to Saussure: Essays on the Study of Intellectual History. Minneapolis: University of Minnesota Press.

1983. The Study of Language in England, 1780-1860. Minneapolis: University of Minnesota Press.

Condillac, Étienne Bonnot, Abbé de. 1947-51. Oeuvres philosophiques. 3 vols., ed. Georges le Roy. Paris: Presses Universitaires de France. 
De Man, Paul. 1979. Allegories of Reading. New Haven and London: Yale University Press.

Diderot, Denis. 1751. Lettre sur les sourds et muets. Paris.

Harris, Roy, and Taylor, Talbot J. 1989. Landmarks in Linguistic Thought. London and New York: Routledge.

Herder, Johann Gottfried. 1966. Essay on the Origin of Language. Trans. John H. Moran and Alexander Gode. Chicago and London: University of Chicago Press.

1969. J.G. Herder on Social and Political Culture. Trans. F.M. Barnard. London: Cambridge University Press.

Hobbes, Thomas. 1839. Elements of Philosophy. Trans. William Molesworth. London: Bohn.

Humboldt, Wilhelm von. 1988. On Language: The Diversity of Human Language-Structure and its Influence on the Mental Development of Mankind. Trans. Peter Heath. Cambridge: Cambridge University Press.

Hundert, E.J. 1988. 'The Thread of Language and the Web of Dominion: Mandeville to Rousseau and Back.' Eighteenth-Century Studies. 21.169-91.

Johnson, Samuel. 1755. Preface to A Dictionary of the English Language. In Samuel Johnson. Ed. Donald J. Green. Oxford and New York: Oxford University Press, 1984.

Kretzmann, Norman. 1976. 'The Main Thesis of Locke's Semantic Theory.' In History of Linguistic Thought and Contemporary Linguistics. Ed. Herman Parret. Berlin and New York: Walter de Gruyter.

Land, Stephen. 1986. The Philosophy of Language in Britain. New York: AMS Press.

Le Clerc, Jean. 1685. Sentimens de quelque théologiens de Hollande sur l'Histoire de Vieux Testiment. Amsterdam.

Leroy, Maurice. 1967. The Main Trends in Modern Linguistics. Trans. G. Price. Oxford: Blackwells.

Locke, John. 1975. An Essay Concerning Human Understanding. Ed. Peter H. Nidditch. Oxford: Clarendon Press.

Manchester, Martin L. 1985. The Philosophical Foundations of Humboldt's Linguistic Doctrines. Amsterdam and Philadelphia: John Benjamins.

Mandeville, Bernard. 1924. The Fable of the Bees. Ed. F.B. Kaye. Oxford: Clarendon Press.

Monboddo, James Burnett, Lord. 1773-92. Of the Origin and Progress of Language. 6 vols. Edinburgh.

Rousseau, Jean-Jacques. 1964. Oeuvres Complètes. 3 vols. Paris: Gallimard.

Schreyer, Rüdiger. 1978. 'Condillac, Mandeville, and the Origin of Language' Historiographia Linguistica. 5.13-43.

Simon, Richard. 1678. Histoire critique du Vieux Testiment. Paris.

Sweet, Paul R. 1988. 'Wilhelm von Humboldt, Fichte, and the Idéologues (1794-1805).' Historiographia Linguistica. 15. 349-75. 